\title{
Orthodontic Mini-implants: Are They a Good Anchorage Resource for Cases of Retraction After Extraction?
}

\author{
Mini-implantes en Ortodoncia: ¿Son un Buen Recurso de Anclaje \\ para los Casos de Retracción Después de la Extracción Dentaria?
}

\begin{abstract}
Matheus Melo Pithon*; Rogério Lacerda dos Santos*; Mônica Tirre de Souza Araújo** \& Lucianne Cople Maia***
\end{abstract}
PITHON, M. M.; DOS SANTO, R. L.; ARAÚJO, M. T. S. \& MAIA, L. C. Orthodontic mini-implants: are they a good anchorage resource for cases of retraction after extraction? Int. J. Odontostomat., 6(3):369-374, 2012.

ABSTRACT: The aim was to seek scientific evidence in the literature that orthodontic mini-implants provide absolute anchorage during the retraction of maxillary anterior teeth after pre-molar extractions. A search was undertaken in the two databases Ovid and Pub Med. The key words "miniscrew", "mini-implants", "orthodontic anchorage procedure", "Anchorage loss", "tooth movement" and "orthodontic space closure" were used. After the initial search, repeated articles in the databases were excluded, then selection was based on the inclusion and exclusion criteria, using a table developed for this purpose. Of the 550 articles initially listed, 4 were found to be potentially eligible, ending with 3 being selected after applying the inclusion and exclusion criteria. According to the quality required, only 3 of these articles attained a high enough score to be evaluated. Two of these articles showed absolute anchorage provided by mini-implants, and the other demonstrated slight loss of anchorage. There are strong scientific evidences that orthodontic mini-implants provide absolute anchorage during the retraction of maxillary teeth.

KEY WORDS: miniscrew, mini-implant, anchorage.

\section{INTRODUCTION}

During orthodontic treatment, precise diagnosis and correct formulation of the treatment plan afterwards are highly difficult and complex procedures. When defining the treatment plan, a significant percentage of malocclusions, such as discrepancies between the size of teeth and maxilla, and discrepancies between the bony bases normally result in a therapy involving extractions (Ricketts, 1976; Noroozi, 2000).

Closing the spaces left by the extractions must be performed in a planned and adequate manner (Shpack et al., 2008). For this purpose, according to orthodontic planning, the teeth will be partially or completely retracted. This decision depends on the requirements of the case and the type of anchorage that will be used (Burstone, 1982).

Orthodontic anchorage has been a reason for concern to orthodontists since the beginning of the specialty. Successful orthodontic therapy, to a large extent, depends on the judicious planning of anchorage, and it is no exaggeration to affirm that this factor is one of the determinants of success or failure of many treatments.

At present, mini-implants have been used to improve situations that need anchorage (Kanomi, 1997; Melsen \& Costa, 2000; Melsen, 2005; Nojima et al., 2006). The reason for using them is the versatility of their positioning, and their easy removal and low cost (Araújo et al., 2006; Nascimento et al., 2006; Nojima et al.).

In certain clinical situations, in which the extraoral appliance would be indicated as an aid to anchorage, mini-implants have been successfully used instead (Kuroda et al., 2007; Sugawara et al., 2008). This fact is relevant because one of the major problems during orthodontic treatment with extra-oral appliances is the patient's lack of cooperation (Park et al., 2006).

* Doctor of Orthodontics from the Federal University of Rio de Janeiro - UFRJ, Rio de Janeiro, Brazil.

*Adjunct Professor, Department of Pediatric Dentistry and Orthodontics, Federal University of Rio de Janeiro - UFRJ, Rio de Janeiro, Brazil.

${ }^{* * *}$ Full Professor, Department of Pediatric Dentistry and Orthodontics, School of Dentistry, Federal University of Rio de Janeiro - UFRJ, Rio de Janeiro, Brazil. 
Although there is consensus among clinicians about the good role played by mini-implants, a detailed analysis of published scientific studies is pertinent. Starting from this premise, the aim of this study was to seek evidences in the international literature about the effectiveness of using orthodontic mini-implants as an anchorage resource in cases of closing spaces after pre-molar extraction, by performing a systematic review.

\section{MATERIAL AND METHOD}

The search for articles was carried out using the Ovid and Pub Med databases. The search comprised articles published in the period from January 1997 to March 2009, in all the languages found. The key words used were: "miniscrew", "mini-implants", "orthodontic anchorage procedure", "Anchorage loss", "tooth movement" and "orthodontic space closure".
After the initial search in the databases, a preselection was made by reading the titles and abstracts. After listing the articles of interest, the inclusion and exclusion criteria were applied (Table I). After this, a classification table was used, which ranked the articles in accordance with the scores received due to the methodological characteristics shown in Table II. The classification followed the ten requirements shown in the table. The article that obtained from 1 to 2 items was ranked as bad, from 3 to 4 as average, from 5 to 6 as good, 7 to 8 as very good and from 9 to 10 as excellent. That is to say, if the article fulfilled the requirement in question, it scored 1 , if not, it scored 0 and at the end the requirements were added up and the article was fit into a classification.

It should be pointed out that the search for articles was performed by two examiners. After individual selection, the examiners met to solve problems of divergence that might have occurred during individual selection. Articles in which the data required for good understanding were not explicit, the authors were contacted.

Table I. Inclusion and exclusion criteria used.

\begin{tabular}{ll}
\hline Inclusion Criteria & Exclusion Criteria \\
\hline in vivo experimental studies (humans) & Experimental studies in animals \\
Healthy individuals & Literature reviews \\
Cases of tooth biprotrusion in which the treatment proposal was pre-molar extraction & Clinical cases \\
The orthodontic mini-implant anchorage resource was used & Editorial letters \\
Randomized and clinical experimental studies & in vitro studies \\
\hline
\end{tabular}

Fig. 1. Flow sheet of the articles during selection process.
Search Home

427 Articles in OVID

123 Articles in Pub Med
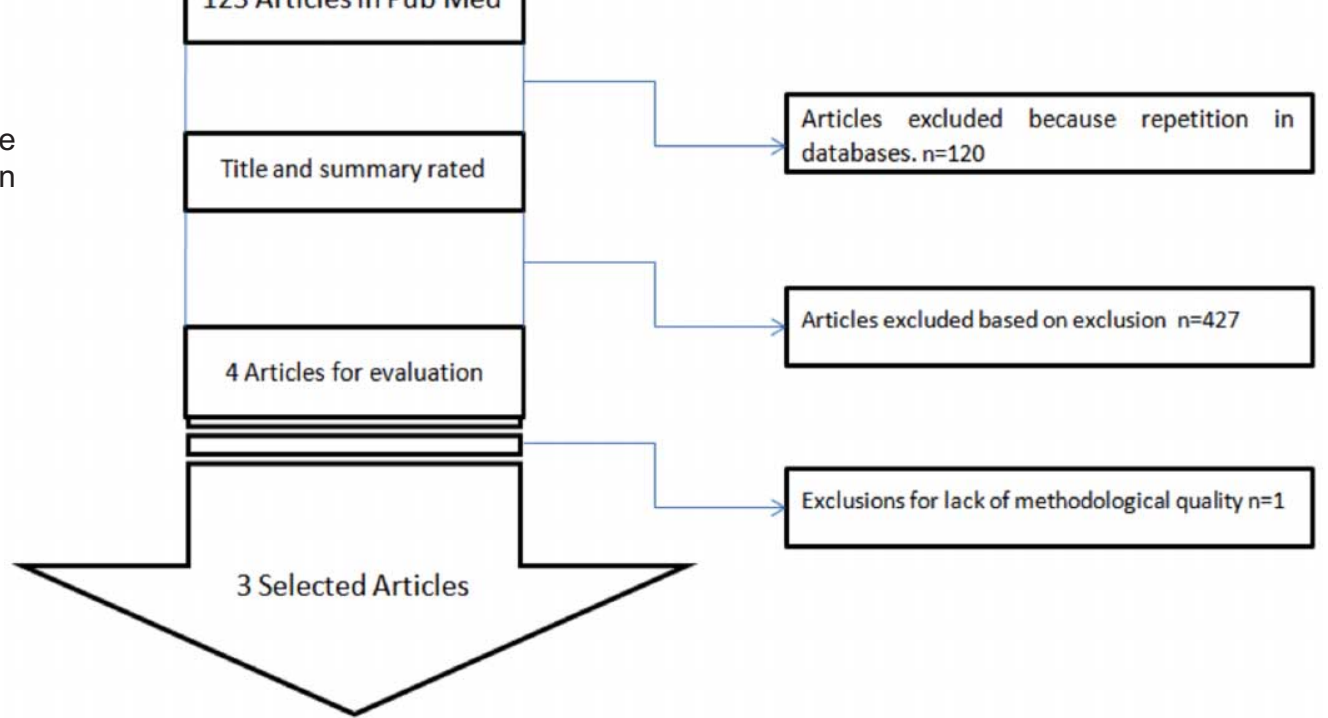


\section{RESULTS}

After searching the Ovid and Pub Med databases, a total of 550 articles were found. Initially, a total number of 120 articles repeated in the two databases were excluded. After this first elimination, the titles and abstracts of the selected articles were read, and after this reading, a total of 427 articles were excluded, based on the exclusion criteria (Table I).

At the end, 4 articles were selected and only 3 (Upadhyay et al., 2008a, 2008b) attained a sufficiently high score to be included in the sample (Table II). These 3 articles were read in full and discussed (Table III). The article by Upadhyay et al. (2008a, 2008b) scored 9 and the one by Kokitsawat et al. (2008) scored 5 points.

\section{DISCUSSION}

Orthodontic anchorage has always been a widely discussed subject in the orthodontic literature. Whether or not anchorage is lost is directly related to the success or failure of orthodontic cases. Since the beginning of orthodontics as a science, concern about anchorage has tormented orthodontists. Several devices were idealized and used for this purpose. Nevertheless, up until the mid 1990s, only extra-oral appliances were capable of anchoring teeth with few undesirable effects. However, as these devices are placed extra-orally, as the name itself indicates, it makes them anti-esthetic and thus, unacceptable to use in a society that places a high value on esthetics.

Starting with this presupposition, the aim of this study was to systematically review the articles available in the international literature, assessing the performance of mini-implant devices when used as a resource for anchorage in cases of tooth retraction after maxillary pre-molar extraction.

For this purpose Ovid and Pub Med, the two main scientific databases were searched. The search took place from January 1997 to January 2009. The date chosen for starting the research was because this was the year when the first article on mini-implants for orthodontic purposes was published (Kanomi).

The study began with 550 articles, but when reviewing those that had been found in the two databases, applying the inclusion and exclusion criteria and quality chart, only three articles of interest remained.

The three articles selected were published in 2008, and two of these articles were written by the same authors using different samples. This information was obtained when the authors were contacted.

The first article in order of publication was by Upadhyay et al. (2008a) published in July 2008. The aim of this article was to assess the effectiveness of mini-implants as an anchorage resource during retraction of anterior teeth. Cephalometric measurements, in which there were stable anatomic points, were used. The results found in the study showed absolute anchorage provided by mini-implants, whereas the traditional methods demonstrated loss of anchorage. Another datum provided

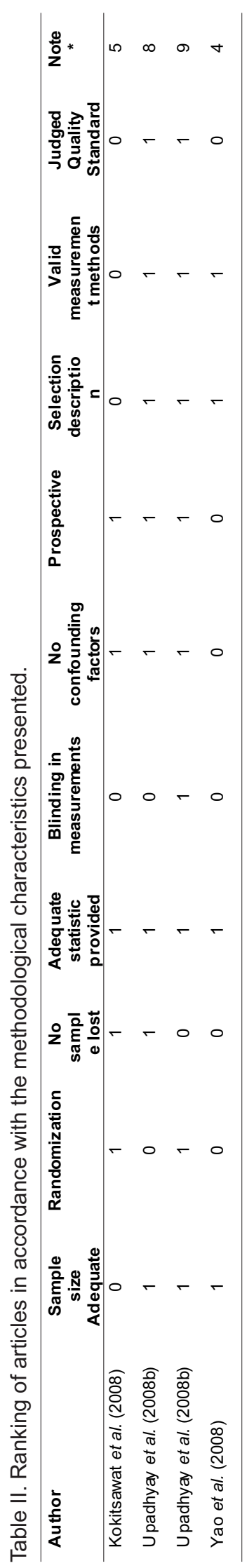




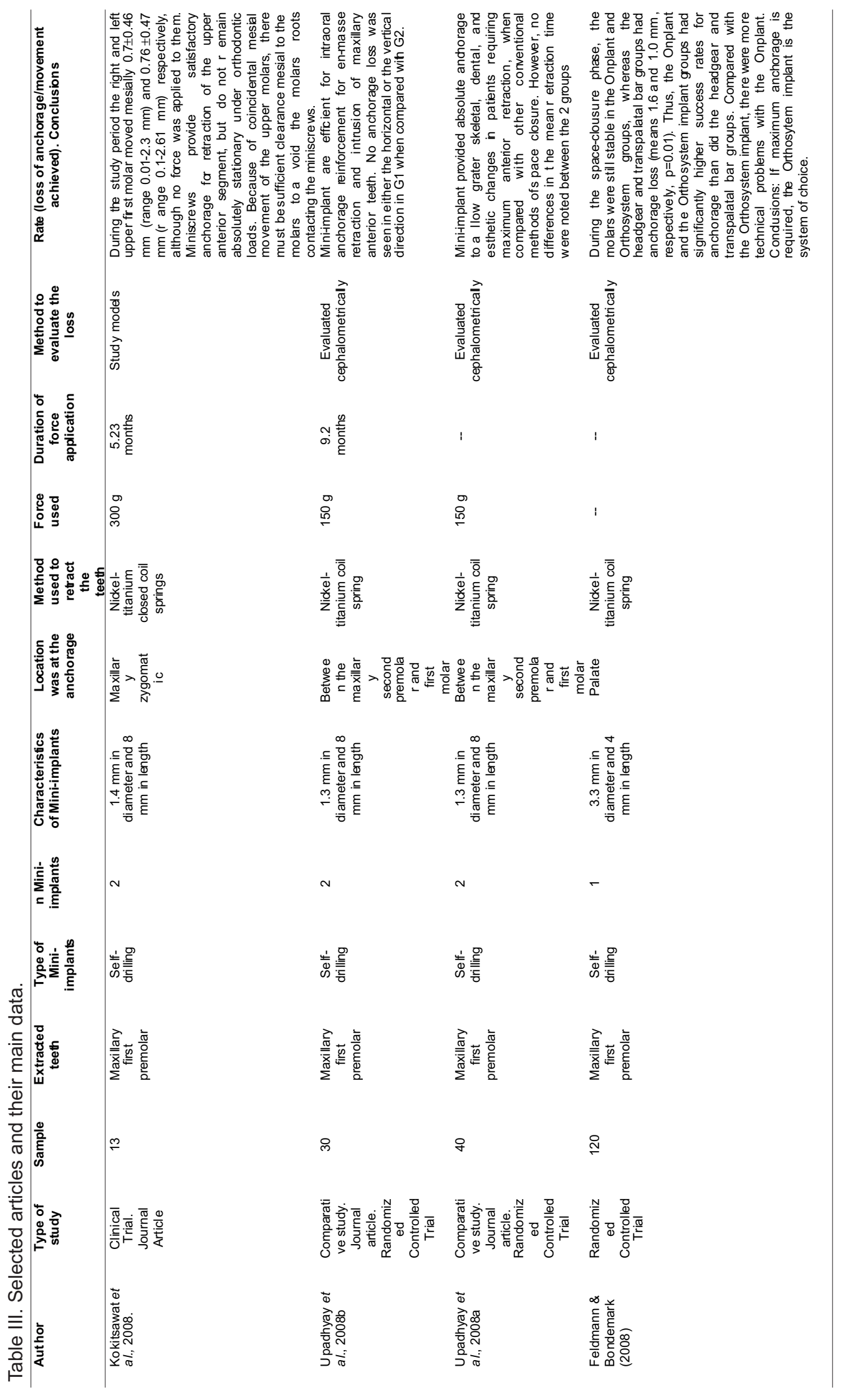

by the authors was that mini-implants had a success rate of $93 \%$; that is, these mini-implants remained stable at this percentage. As there was no loss of anchorage in the group in which miniimplants were used, the changes in the face and mandibular plane were more notable.

The other article published by the authors Upadhyay et al. (2008b) in December 2008, presented the same proposal as the previous one, but the difference between the articles was due to methodological changes, such as non-randomization, $\mathrm{n}$ o $\mathrm{n}$ - b lin d e d assessments and a different sample consecutively. The proposal of the study was the same; that is to compare traditional methods of anchorage with mini-implants in the retraction of anterior teeth after pre-molar extraction. The results found in the study showed the effectiveness of mini-implants during retraction without loss of anchorage.

From a methodological point of view, this article 
was ranked with a lower score than the previous one, and hypothetically, if the results found were different, one would give greater weight to the results provided by the article published in July.

In short, in their two articles, Upadhyay et al. (2008a, 2008b) concluded that mini-implants were shown to be an efficient mechanism of anchorage during the movements of retraction and intrusion of maxillary anterior teeth, with no loss of anchorage both in the horizontal and vertical directions, when compared with the traditional methods. The authors emphasized the need to perform a study with a larger sample.

Kokitsawat et al., also endeavoring to also assess the effectiveness of mini-implants, conducted a study in which the analysis was performed in plaster models. The results found by these authors were in disagreement with those of Upadhyay et al. (2008a, 2008b). According to Kokitsawat et al., there was a loss of anchorage when these devices were used. These results may have been found due to some methodological failures while the study was conducted, such as the use of non-stable points in the plaster models. It is important to remember that as regards the classification of this study for inclusion in the present study, the article obtained the minimum scores required, so that when analyzing the results presented in it in comparison with those of the other articles, it remains in second place.

By assessing the articles selected it can be affirmed that there are strong scientific evidences that orthodontic mini-implants provide absolute anchorage during retraction of maxillary teeth.

\section{CONCLUSION}

After having performed this systematic review, it could be concluded that there are strong evidences that orthodontic mini-implants are an effective means of anchorage, and prevent undesirable movements of mesialization of the posterior teeth to the postextraction space of maxillary pre-molars.

PITHON, M. M.; DOS SANTO, R. L.; ARAÚJO, M. T. S. \& MAIA, L. C. Mini-implantes en ortodoncia: ¿son un buen recurso de anclaje para los casos de retracción después de la extracción dentaria? Int. J. Odontostomat., 6(3):369-374, 2012.

RESUMEN: El objetivo fue buscar en la literatura evidencia científica que los mini-implantes ortodóncicos proporcionan un anclaje absoluto durante la retracción de los dientes anteriores superiores después de la extracción de los premolares. La búsqueda se realizó dos bases de datos: Ovid y PubMed. Fueron utilizadas las palabras clave "mini tornillo", "miniimplantes", "procedimiento de anclaje ortodóntico", "pérdida de anclaje", "movimiento de los dientes" y "cierre ortodóntico de los espacios ". Después de la búsqueda inicial, los artículos repetidos en las bases de datos fueron excluidos, y la selección se basó en los criterios de inclusión y exclusión, usando una tabla desarrollado para este propósito. De los 550 artículos inicialmente enumerados, 4 resultaron ser potencialmente elegibles, y se terminó con la selección de 3 artículos luego de aplicar los criterios de inclusión y exclusión. De acuerdo con la calidad requerida, sólo 3 artículos alcanzaron una puntuación lo suficientemente alta como para ser evaluados. Dos de estos artículos mostraron un anclaje absoluto proporcionado por los mini-implantes, y el otro demostró una ligera pérdida de anclaje. Existen fuertes evidencias científicas que los mini-implantes ortodónticos proporcionan un anclaje absoluto durante la retracción de los dientes maxilares.

PALABRAS CLAVE: minitornillos, mini-implante, anclaje.

\section{REFERENCES}

Araújo T. M.; Nascimento, M. H. A.; Bezerra, F. \& Sobral, M. C. Skeletal anchorage in Orthodontics with mini-implants. R. Dental Press Ortodon. Ortop. Facial, 11(4):126-56, 2006.

Burstone, C. J. The segmented arch approach to space closure. Am. J. Orthod., 82(5):361-78, 1982.

Feldmann, I. \& Bondemark, L. Anchorage capacity of osseointegrated and conventional anchorage systems: a randomized controlled trial. Am. J. Orthod. Dentofacial Orthop., 133(3):339.e19-28, 2008.

Kokitsawat, S.; Manosudprasit, M.; Godfrey, K. \& Chatchaiwiwattana, C. Clinical effects associated with miniscrews used as orthodontic anchorage. Aust. Orthod. J., 24(2):134-9, 2008. 
Kanomi, R. Mini-implant for orthodontic anchorage. J. Clin. Orthod., 31(11):763-7, 1997.

Kuroda, S.; Yamada, K.; Deguchi, T.; Hashimoto, T.; Kyung, H. M. \& Takano-Yamamoto, T. Root proximity is a major factor for screw failure in orthodontic anchorage. Am. J. Orthod. Dentofacial Orthop., 131(4 Suppl.):S68-73, 2007.

Melsen, B. Mini-implants: Where are we? J. Clin. Orthod., 39(9):539-47; quiz 531-2, 2005.

Melsen, B. \& Costa, A. Immediate loading of implants used for orthodontic anchorage. Clin. Orthod. Res, 3(1):23-8, 2000.

Nascimento, M. H. A.; Araújo, T. M. \& Bezerra, F. Orthodontic micro-screw: installation and periimplant hygienic orientation. R. Clin. Ortodon. Dental Press, 5(1):24-31, 2006.

Nojima, L. I.; Gonçalves, M.; Melgaço, C. A.; Costa, L. F. M. \& Bernardes, J. Dispositivos temporários de ancoragem em Ortodontia. In: Estética em implantes - Uma abordagem dos tecidos moles e duros. São Paulo, Santos, 2006.

Noroozi, H. A Formula to Determine the Amount of Retraction of Mandibular Canines. Angle Orthod., 70(2):154-6, 2000.

Park, H. S.; Jeong, S. H. \& Kwon, O. W. Factors affecting the clinical success of screw implants used as orthodontic anchorage. Am. J. Orthod. Dentofacial Orthop., 130(1):18-25, 2006.

Ricketts, R. M. Bioprogressive therapy as an answer to orthodontic needs. Part II. Am. J. Orthod., 70(4):359-97, 1976.

Shpack, N.; Davidovitch, M.; Sarne, O.; Panayi, N. \& Vardimon, A. D. Duration and anchorage management of canine retraction with bodily versus tipping mechanics. Angle Orthod., 78(1):95100, 2008.

Sugawara, Y.; Kuroda, S.; Tamamura, N. \& TakanoYamamoto, T. Adult patient with mandibular protrusion and unstable occlusion treated with titanium screw anchorage. Am. J. Orthod. Dentofacial Orthop., 133(1):102-11, 2008.
Upadhyay, M.; Yadav, S.; Nagaraj, K. \& Patil, S. Treatment effects of mini-implants for en-masse retraction of anterior teeth in bialveolar dental protrusion patients: a randomized controlled trial. Am. J. Orthod. Dentofacial Orthop., 134(1):18-29 e11, 2008a.

Upadhyay, M.; Yadav, S. \& Patil, S. Mini-implant anchorage for en-masse retraction of maxillary anterior teeth: a clinical cephalometric study. Am. J. Orthod. Dentofacial Orthop., 134(6):803-10, 2008b.

Yao, C. C.; Lai, E. H.; Chang, J. Z.; Chen, I. \& Chen, Y. J. Comparison of treatment outcomes between skeletal anchorage and extraoral anchorage in adults with maxillary dentoalveolar protrusion. $\mathrm{Am}$. J. Orthod. Dentofacial Orthop., 134(5):615-24, 2008.

Correspondence to:

Lucianne Cople Maia

Department of Paediatric Dentistry and Orthodontics

School of Dentistry

Federal University of Rio de Janeeiro

Av. Brigadeiro Trompowisky, s/n

Ilha do Fundão

Rio de Janeiro, RJ

BRAZIL

Email: rorefa@terra.com.br

Received: 28-04-2012

Accepted: 29-08-2012 